\title{
Cross-sectional survey for toxoplasmosis in free-range chickens (Gallus gallus domesticus) from the Atlantic Forest area in Alagoas state, Northeastern Brazil
}

\author{
Estudo transversal para toxoplasmose em galinhas caipiras (Gallus gallus \\ domesticus) de área de Mata Atlântica do estado de Alagoas, Nordeste do Brasil \\ Beatriz Maria de Almeida Braz ${ }^{*}$ (1); Bruna Catarina de Oliveira Feitosa²; Elton Amorim Romão²; \\ Edson Moura da Silva²; José Wilton Pinheiro Júnior ${ }^{3}$; Rinaldo Aparecido Mota3; Sérgio Santos de Azevedo; \\ Wagnner José Nascimento Porto² \\ 1 Universidade Federal de Campina Grande - UFCG, Patos, PB, Brasil \\ ${ }^{2}$ Laboratório de Doenças Parasitárias, Universidade Federal de Alagoas - UFAL, Viçosa, AL, Brasil \\ ${ }^{3}$ Laboratório de Doenças Infectocontagiosas dos Animais Domésticos, Departamento de Medicina Veterinária, Universidade Federal \\ Rural de Pernambuco - UFRPE, Recife, PE, Brasi
}

How to cite: Braz BMA, Feitosa BCO, Romão EA, Silva EM, Pinheiro Júnior JW, Mota RA, et al. Cross-sectional survey for toxoplasmosis in free-range chickens (Gallus gallus domesticus) from the Atlantic Forest area in Alagoas state, Northeastern Brazil. Braz J Vet Parasitol 2020; 29(4): e014120. https://doi.org/10.1590/S1984-29612020087

\begin{abstract}
Toxoplasmosis is a parasitic disease, which is prevalent across the world and has a strong environmental component in its transmission chain. The present study determined the seroprevalence and factors related to Toxoplasma gondii infection among free-range chickens from an Atlantic Forest area in Northeastern Brazil. A total of 550 free-range chickens were tested for T. gondii antibodies usingthe indirect fluorescent antibody test (IFAT, cut-off point 1:16), and 269 (48.9\%; 95\% Cl = 44.7-53.1\%) were positive. Among the 61 properties 57 (93.4\%) had at least one seropositive animal. The robust Poisson regression model showed that the variables/categories associated with the seroprevalence of $T$. gondii were: region of origin of the animals/urban area (prevalence ratio $[P R]=2.346 ; P<0.001)$, management system/use of cages $(P R=1.591 ; P=0.019)$, presence of rodents/yes $(P R=1.295 ; P=0.035)$, and the type of food/use of food scraps $(P R=1.603 ; P=0.009)$. The high prevalence found suggest that this scenario demands careful management, mainly regarding the use of scraps of undercooked or raw food, adequate environmental hygiene and frequent rodentcontrol.
\end{abstract}

Keywords: T. gondii, serology, free-range chickens, epidemiology, prevalence.

\begin{abstract}
Resumo
A toxoplasmose é uma doença parasitária mundial com um forte componente ambiental em sua cadeia de transmissão. Nesta pesquisa, foram determinados a soroprevalência e os fatores associados em galinhas caipiras de uma área de Mata Atlântica no Nordeste do Brasil. Um total de 550 galinhas caipiras foi testado para anticorpos anti-Toxoplasma gondii pela reação de imunfluorescência indireta (RIFI) com ponto de corte de 1:16, e 269 (48,9\%; IC95\% = 44,7- 53,1\%) foram positivas. Das 61 propriedades visitadas, 57 (93,4\%) apresentaram pelo menos um animal positivo. $\mathrm{O}$ modelo de regressão de Poisson robusta mostrou que as variáveis/categorias associadas à soroprevalência de $T$. gondii foram: origem dos animais/área urbana (razão de prevalência - $R P=2,346 ; P<0,001$ ), sistema de manejo/uso de gaiolas ( $\mathrm{RP}=1,591 ; P=0,019)$, presença de roedores/sim ( $\mathrm{RP}=1,295 ; P=0,035)$, e tipo de alimento/uso de sobras de alimentos $(R P=1,603 ; P=0,009)$. A alta prevalência sugereque este cenário demanda cuidados de manejo, principalmente no que se refere ao fornecimento de sobras de alimentos mal cozidos ou crus, higiene adequada do meio ambiente e controle frequente de roedores.
\end{abstract}

Palavras-chave: T. gondii, sorologia, galinhas caipiras, epidemiologia, prevalência.

Received June 12, 2020. Accepted august 14, 2020.

*Corresponding author: Beatriz Maria de Almeida Braz. E-mail: beatrizbraz89@hotmail.com 
Toxoplasmosis is a zoonotic disease with a worldwide distribution, caused by an intracellular Coccidia, Toxoplasma gondii. Domestic cats and other felids are the known definitive hosts of the agent, which can eliminate viable oocysts through their feces (Dubey, 2010). Free-range chicken farming is an income-generating enterprise, which provides a nutritional alternative for low-income families, especially in Northeastern Brazil. In the afore said region, the production scale continues to increase every year and the product is largely consumed by internal consumers. However, these animals can get infected by ingesting $T$. gondii oocysts because they feed from the ground and they are considered as good indicators of environmental contamination (Dubey et al., 2012). In addition, free-range chickens have an epidemiological significance because raw or undercooked chicken meat is a major source of infection for humans and other animals, if consumed or handled without proper hygiene (Casartelli-Alves et al., 2015). Moreover, it is worth mentioning that in previous studies T. gondii was isolated from free-range chickens in Northeastern Brazil and in the municipality investigated in this study (Clementino Andrade et al., 2013; Feitosa et al., 2016; Santos Silva et al., 2020).

To our knowledge, serological surveys using planned sampling of free-range chickens in the regions of fragmented Atlantic Forest are very few.In the present study, a cross-sectional survey was carried out to determine the prevalence and the factors associated with T. gondii infection in free-range chickens (Gallus gallus domesticus) from an area of fragmented Atlantic Forest in the state of Alagoas, Northeastern Brazil, specifically in the county of Viçosa. According to the Empresa Brasileira de Pesquisa Agropecuária (EMBRAPA), the afore mentioned geographic region has high humidity, the climate is tropical with rains from autumn to winter and a well-defined dry season. The average annual rainfall varies from $1.300 \mathrm{~mm}$ to $1.400 \mathrm{~mm}$. The above-mentioned conditions, together with the peculiarities of the predominant vegetation, sub-perennial forests with a rich biodiversity, present epidemiological conditions that need to be analyzed in a different manner compared to other regions.

All procedures were approved by the Committee on Ethics in the Use of Animals (CEUA - Federal University of Alagoas, Protocol No. 43/2015). The formula for simple random sampling was used to calculate the sample size (Thrusfield, 2004) and the following parameters were taken into consideration: expected prevalence of 50\% (sample maximization), confidence level of $95 \%$ and a statistical error of $5 \%$, which resulted in an estimated minimum sample size of 384 animals. However, 550 animals from 61 farms were included in the study; 251 from urban and 299 from rural areas. Blood samples were collected through a puncture of the brachial vein from March to June 2015.

The indirect fluorescent antibody test (IFAT) was used to detect anti-T. gondii antibodies in the serum samples, as described by Camargo (1964). The tachyzoites of $T$. gondii from the RH reference strain, fixed on a slide, were used as antigens. Samples known to be positive and negative were used as controls in each slide, and the anti-chicken IgG conjugate from Sigma-Aldrich (reference F4137). The samples were read in double blind to confirm the result. A cut-off point of 1:16 (Millar et al., 2012) was considered as the indicator of seropositivity.

All the owners involved in the study answered epidemiological questionnaires and the data collected were used to analyze the factors associated with the seroprevalence of $T$. gondii. The variables and respective categories analyzed are presented in Table 1. The data obtained from the epidemiological questionnaires and serological tests were stored in a Microsoft Excel software database.

Initially, association analyses (univariable analysis) between each independent variable and the dependent variable (seropositivity in serological tests) were performed. Variables with $P$-values less than or equal to 0.2 in the chi-squared test were selected for the multivariable analysis using the robust Poisson regression model. Collinearity between independent variables was verified through a correlation analysis (cut-off: correlation coefficient $>0.9$ ) (Dohoo et al., 2003). The Omnibus test was used to verify the significance of the model, and the Pearson chi-squared test was applied to verify the goodness-of-fit of the final model. The current study assumed a significance level of $5 \%$ in the multiple analyses. The statistical analyses were performed using the SPSS software for Windows, version 20.0.

Among the 550 serum samples evaluated, $269(48.9 \% ; 95 \% \mathrm{Cl}=44.7-53.1 \%)$ were positive for anti- $T$. gondii IgG antibodies and among the 61 properties involved in the survey, 57 (93.4\%) had at least one infected animal. The results of the univariable analysis and the variables selected for multivariable analysis are presented in Table 1. The sample size available for analyses of some of the variables was less than the total sample size of the current study ( $n=550$ ) on account of the inadequate data collection by the interviewers. The final robust Poisson regression model is shown in Table 2 . The variables' categories associated with the seroprevalence of $T$. gondii were as follows: urban area (Prevalence ratio $[\mathrm{PR}]=2.346 ; 95 \% \mathrm{Cl}=1.801-3.056 ; P<0.001$ ), use of cages $(\mathrm{PR}=1.591$; $95 \% \mathrm{Cl}=1.078-2.350 ; P=0.019)$, presence of rodents $(\mathrm{PR}=1.295 ; 95 \% \mathrm{Cl}=1.018-1.647 ; P=0.035)$ and use of food scraps ( $P R=1.603 ; 95 \% \mathrm{Cl}=1.126-2.282 ; P=0.009)$. The final model presented good fit (Pearson chi-squared value $=254.94$; degree of freedom $(\mathrm{df})=480$; value $/ \mathrm{df}=0.531)$. 
Table 1. Univariable analysis of factors associated with the seroprevalence of toxoplasmosis infree-range chickens from the Atlantic Forest area of the Alagoas state, Northeastern Brazil.

\begin{tabular}{|c|c|c|c|c|}
\hline Variable & Categories & $\begin{array}{l}\text { Total number of } \\
\text { chickens }\end{array}$ & $\begin{array}{c}\text { Number } \\
\text { of positive } \\
\text { chickens (\%) }\end{array}$ & $P$-value \\
\hline \multirow[t]{2}{*}{ Origin of the animals } & Rural area & 299 & $92(30.8 \%)$ & \\
\hline & Urban area & 251 & $177(70.5 \%)$ & $<0.001 *$ \\
\hline \multirow[t]{3}{*}{ Management system } & Extensive & 374 & $165(44.1 \%)$ & \\
\hline & Cages & 47 & $34(72.3 \%)$ & \\
\hline & Extensive/cages & 120 & $64(53.34 \%)$ & $0.001 *$ \\
\hline \multirow[t]{3}{*}{ Backyard division } & Fence & 447 & $194(43.4 \%)$ & \\
\hline & Wall & 74 & $57(77 \%)$ & \\
\hline & Others & 20 & $12(60 \%)$ & $<0.001$ * \\
\hline \multirow[t]{2}{*}{ Presence of cats } & Yes & 460 & $219(47.6 \%)$ & \\
\hline & No & 81 & $44(54.3 \%)$ & 0.320 \\
\hline \multirow[t]{2}{*}{ Presence of rodents } & Yes & 74 & $51(68.9 \%)$ & \\
\hline & No & 467 & $212(45.4 \%)$ & $<0.001$ * \\
\hline \multirow[t]{2}{*}{ Presence of other animals } & Yes & 453 & $204(45 \%)$ & \\
\hline & No & 88 & $59(67 \%)$ & $<0.001 *$ \\
\hline \multirow[t]{4}{*}{ Type of food } & Commercial food & 124 & $38(30.6 \%)$ & \\
\hline & Food scraps & 73 & $40(54.8 \%)$ & \\
\hline & Commercial/food scraps & 337 & $182(54 \%)$ & \\
\hline & Others & 7 & $3(42.9 \%)$ & $<0.001 *$ \\
\hline \multirow[t]{3}{*}{ Feeding arrangements } & Chicken feeders & 131 & $58(44.3 \%)$ & \\
\hline & On the ground & 377 & $196(52 \%)$ & \\
\hline & Both & 33 & $9(27.3 \%)$ & $0.013^{*}$ \\
\hline \multirow[t]{4}{*}{ Cat feces disposal } & On the ground & 244 & $133(54.5 \%)$ & \\
\hline & Near pastures & 8 & $6(75 \%)$ & \\
\hline & Near water troughs & 18 & $9(50 \%)$ & \\
\hline & On the ground/near pastures & 226 & $85(37.6 \%)$ & $0.001 *$ \\
\hline
\end{tabular}

*Variables selected for robust Poisson regression; $P$-value = probability of rejecting the null hypothesis when it is actually true.

Table 2. Factors associated with the seroprevalence of toxoplasmosis in free-range chickens from the Atlantic Forest area of the Alagoas state, Northeastern Brazil.

\begin{tabular}{ccccccc}
\hline Variable category & $\begin{array}{c}\text { Coefficient } \\
\text { estimates }\end{array}$ & $\begin{array}{c}\text { Standard } \\
\text { error }\end{array}$ & $\begin{array}{c}\text { Wald chi- } \\
\text { squared }\end{array}$ & $\begin{array}{c}\text { Prevalence } \\
\text { ratio (PR) }\end{array}$ & 95\% Cl for PR & P-value \\
\hline Urban area & 0.853 & 0.135 & 39.960 & 2.346 & $1.801-3.056$ & $<0.001$ \\
Use of cages & 0.465 & 0.199 & 5.457 & 1.591 & $1.078-2.350$ & 0.019 \\
Presence of rodents & 0.258 & 0.123 & 4.422 & 1.295 & $1.018-1.647$ & 0.035 \\
Use of food scraps & 0.472 & 0.180 & 6.858 & 1.603 & $1.126-2.282$ & 0.009 \\
\hline
\end{tabular}

Pearson chi-squared value $=254.94$; degree of freedom $(\mathrm{df})=480$; value $/ \mathrm{df}=0.531 ; 95 \% \mathrm{Cl}=$ Confidence interval of $95 \%$ for prevalence ratio; $P$-value $=$ probability of rejecting the null hypothesis when it is actually true. 
According to Casartelli-Alves et al. (2014), the modified agglutination test (MAT) was used for anti-T. gondii antibody detection in free-range chickens and proved to be simple, low cost and does not require a specific conjugate, being the first choice when compared to the enzyme-linked immunosorbent assay (ELISA) and IFAT. However, the properly standardized IFAT can produce high sensitivity and specificity, being a reproducible option when available, and very effective using cut-off $\geq 16$ in field studies in chickens. The prevalence rate in the current study was higher compared to most of the recent surveys carried out in Brazil, with the reported rates varying from $17.2 \%$ to $31.5 \%$ (Feitosa et al., 2016; Millar et al., 2012; Sá et al., 2017), which indicates that, compared to intensive industrial systems, T. gondii is more wide-spread in free-range systems and soil is probably the main source of oocysts. Furthermore, the chickens have a shorter life span in the industrial systems and contact with cats and contaminated soil is less likely in this scenario (Liu et al., 2017). The region of fragmented Atlantic Forest in the state of Alagoas is situated in an area with a predominance of hills with altitudes of up to 500 meters, which interferes with the relative humidity of air (about 70\%). The temperature in the area varies from $23^{\circ} \mathrm{C}$ to $28^{\circ} \mathrm{C}$, which can favor the survival and sporulation of $T$. gondii oocysts, as they can resist high temperatures and conditions of moderate humidity and survive for months in the soil (Torrey \& Yolken, 2013).

Toxoplasmosis is an emerging food-borne disease in humans and animals with variable worldwide distribution depending on geographic characteristics and cultural habits of the population. Therefore, the disease is significant from the One Health perspective, as it has a strong environmental component in the transmission chain, which makes it a problem that impacts both human and animal health (Latha \& Hareendran, 2018). The high seroprevalence found here indicate that focusing on the sources of infection is fundamental, since $T$. gondii is directly influenced by the environment, which allows its survival in the form of oocysts in the soil. Considering that free-ranging chickens are raised for domestic consumption, both the handler and the consumer are exposed to the risk of infection, either during the processing of the carcass or due to the consumption of raw or semi-cooked meat (Chumpolbanchorn et al., 2013).

The design of cross-sectional survey is one of the most frequently used study designs in observational studies on animal toxoplasmosis and in veterinary epidemiology, probably because they are rapid, in expensive, of moderate difficulty and the odds ratio (OR) is the most common association measure between an exposure and an outcome. However, when the binary outcome is common, usually with a prevalence greater than $10 \%$, the prevalence ratio (PR) can be over estimated by the OR when the PR is greater than one round estimated when the PR is less than one (Martinez et al., 2017). In the current study, a robust Poisson regression model was used to estimate the PR and determine the factors associated with seroprevalence. Free-range chickens reared in the urban areas were 2.346 times more likely to be seropositive for $T$. gondii, i.e., a 134.6\% increase in prevalence. This may be related to the improper management system because in this area, most of the breeding is done in small clusters in the backyards of houses, generally in unhygienic and unsanitary conditions with a constant circulation of felines (Millar et al., 2012). Moreover, the presence of sewage and garbage in peri-urban areas can increase the chickens' exposure to sources of infection, as they usually feed on the remains of food supplied directly on the ground (Feng et al., 2016).

The use of cages in chicken rearing increased the seroprevalence of T. gondii by 1.591 times (59.1\%). Free-range chickens are deemed more susceptible to $T$. gondii infection and are good indicators of environmental contamination by oocysts because of their habit of scratching and are being used as sentinel animals in the regions with a high prevalence of human toxoplasmosis (Dong et al., 2018). However, in backyard rearing systems, in which chickens are kept in cages, access to oocysts in the soil is limited, and these animals are fed food scraps and ingest untreated water, which are important routes of disease transmission (Millar et al., 2012).

The presence of rodents was associated with a $29.5 \%$ increase in the prevalence of $T$. gondii infection. Rodents and chickens are considered the main intermediate hosts of T. gondii when being hunted by felids (Wang et al., 2013). Nevertheless, the epidemiological importance of rodents in the context of toxoplasmosis is lower, compared to that of chickens, considering that they act as efficient intermediate hosts due to their longevity, are more resistant to the agent and do not develop the clinical disease (Dubey, 2010). It is important to note that the properties involved in the current study had favorable conditions to attract rodents, such as the lack of hygiene and basic sanitation and the accumulation of garbage in the yards.

The use of food scraps for feeding free-range chickens was associated with a $60.3 \%$ increase in the prevalence, indicating that the animals that receive mixed feeding are more likely to be seropositive. This fact may be related to the consumption habits of the owners because in Brazil, eating undercooked meat and feeding animals with leftover meat and raw viscera is a common practice (Sá et al., 2017). In these cases, rectification and improvement 
of management systems is an alternative method, which can be employed to reduce the frequency of the disease in backyard farms (Feitosa et al., 2016).

In the present study a high seroprevalence of $T$. gondii was found in free-range chickens from a fragmented Atlantic Forest area in Northeastern Brazil, which suggests a widespread dissemination of the agent and a significant impact on public health, since these animals are low-cost sources of protein. Therefore, the scenario demands careful management, mainly regarding the use of scrap from undercooked or raw food, adequate environmental hygiene and frequent rodent control.

\section{References}

Camargo ME. Improved technique of indirect immunofluorescence for serological diagnosis of toxoplasmosis. Rev Inst Med Trop São Paulo 1964; 6(3): 117-118. PMid:14177810.

Casartelli-Alves L, Amendoeira MRR, Boechat VC, Ferreira LC, Carreira JCA, Nicolau JL, et al. Mapping of the environmental contamination of Toxoplasma gondii by georeferencing isolates from chickens in an endemic area in Southeast Rio de Janeiro State, Brazil. Geospat Health 2015; 10(1): 311. http://dx.doi.org/10.4081/gh.2015.311. PMid:26054514.

Casartelli-Alves L, Boechat VC, Macedo-Couto R, Ferreira LC, Nicolau JL, Neves LB, et al. Sensitivity and specificity of serological tests, histopathology and immunohistochemistry for detection of Toxoplasma gondii infection in domestic chickens. Vet Parasitol 2014; 204(3-4): 346-351. http://dx.doi.org/10.1016/j.vetpar.2014.05.039. PMid:24953750.

Chumpolbanchorn K, Lymbery AJ, Pallant LJ, Pan S, Sukthana Y, Thompson RCA. A high prevalence of Toxoplasma in Australian chickens. Vet Parasitol 2013; 196(1-2): 209-211. http://dx.doi.org/10.1016/j.vetpar.2013.01.009. PMid:23394799.

Clementino Andrade MM, Pinheiro BV, Cunha MM, Carneiro ACAV, Andrade VF No, Vitor RWA. New gentotypes of Toxoplasma gondii obtained from farm animals in Northeast Brazil. Res Vet Sci 2013; 94(3): 587-589. http://dx.doi.org/10.1016/j.rvsc.2013.01.006. PMid:23395253.

Dohoo IR, Martin W, Stryhn H. Veterinary epidemiologic research. Charlottetown: Atlantic Veterinary College; 2003.

Dong H, Su R, Lu Y, Wang M, Liu J, Jian F, et al. Prevalence, Risk Factors, and Genotypes of Toxoplasma gondii in Food Animals and Humans (2000-2017) From China. Front Microbiol 2018; 9: 2108. http://dx.doi.org/10.3389/fmicb.2018.02108. PMid:30254613.

Dubey JP, Lago EG, Gennari SM, Su C, Jones JL. Toxoplasmosis in humans and animals in Brazil: high prevalence, high burden of disease, and epidemiology. Parasitology 2012; 139(11): 1375-1424. http://dx.doi.org/10.1017/S0031182012000765. PMid:22776427.

Dubey JP. Toxoplasma gondii Infections in chickens (Gallus domesticus): Prevalence, Clinical Disease, Diagnosis and Public Health Significance. Zoonoses Public Health 2010; 57(1): 60-73. http://dx.doi.org/10.1111/j.1863-2378.2009.01274.x. PMid:19744305.

Feitosa TF, Vilela VLR, Almeida-Neto JL, Santos A, Morais DF, Athayde ACR, et al. First study on seroepidemiology and isolation of Toxoplasma gondii in free-range chickens in the semi-arid region of Paraíba state, Brazil. Parasitol Res 2016; 115(10): 3383-3990. http://dx.doi.org/10.1007/s00436-016-5164-5. PMid:27277434.

Feng Y, Lu Y, Wang Y, Liu J, Zhang L, Yang Y. Toxoplasma gondii and Neospora caninum in free-range chickens in Henan province of China. BioMed Res Int 2016; 2016: 8290536. http://dx.doi.org/10.1155/2016/8290536. PMid:27274992.

Latha C, Hareendran S. Studies on Toxoplasma gondii in feline, caprine, human and environment samples: a one health approach. J Vet Med Surgery 2018; 2. http://dx.doi.org/10.4172/2574-2868-C1-002.

Liu X-C, He Y, Han D-G, Zhang Z-C, Li K, Wang S, et al. Detection of Toxoplasma gondii in chicken and soil of chicken farms in Nanjing region, China. Infect Dis Poverty 2017; 6(1): 62. http://dx.doi.org/10.1186/s40249-017-0277-3. PMid:28482918.

Martinez BAF, Leotti VB, Silva GSE, Nunes LN, Machado G, Corbellini LG. Odds ratio or prevalence ratio? An overview of reported statistical methods and appropriateness of interpretations in cross-sectional studies with dichotomous outcomes in veterinary medicine. Front Vet Sci 2017; 4: 193. http://dx.doi.org/10.3389/fvets.2017.00193. PMid:29177157.

Millar PR, Alves FMX, Teixeira VQ, Vicente RT, Menezes EM, Sobreiro LG, et al. Occurrence of infection with Toxoplasma gondii and factors associated with transmission in broiler chickens and laying hens in different raising systems. Pesq Vet Bras 2012; 32(3): 231-236. http://dx.doi.org/10.1590/S0100-736X2012000300009.

Sá SG, Ribeiro-Andrade M, Silva LTR, Souza OL No, Lima DCV, Pedrosa CM, et al. Risk factors associated with Toxoplasma gondii infection in free-range chickens in the semiarid region of Brazil. Rev Bras Parasitol Vet 2017; 26(2): 221-225. http://dx.doi. org/10.1590/s1984-29612017033. PMid:28658418.

Santos Silva AC, de Barros LD, Barros VMC, de Alcântara AM, Andrade MR, Garcia JL, et al. Occurrence of Atypical and new genotypes of Toxoplasma gondii in free-range chickens intended for human consumption in Brazil. Acta Parasitol 2020; 65(3): 774-778. http://dx.doi.org/10.2478/s11686-020-00194-2. PMid:32141021. 
T. gondii in free-range chickens, Northeast Brazil

Thrusfield MV. Epidemiologia veterinária. 2. ed. São Paulo: Roca; 2004.

Torrey EF, Yolken RH. Toxoplasma oocysts as a public health problem. Trends Parasitol 2013; 29(8): 380-384. http://dx.doi. org/10.1016/j.pt.2013.06.001. PMid:23849140.

Wang L, Cheng H-W, Huang K-Q, Xu Y-H, Li Y-N, Du J, et al. Toxoplasma gondii prevalence in food animals and rodents in different regions of China: isolation, genotyping and mouse pathogenicity. Parasit Vectors 2013; 6(1): 273. http://dx.doi.org/10.1186/17563305-6-273. PMid:24330536. 